\title{
Implications of declining household sizes and expectations of home comfort for domestic energy demand
}

Katherine Ellsworth-Krebs

Lancaster Institute for the Contemporary Arts (LICA)

The LICA Building, Lancaster University, Lancaster, UK, LA1 4YW

\section{Acknowledgements:}

I am thankful to Benjamin Kao, Karyn Stewart, and Noah Joubert for their support in finding government data sources (in different languages) on floor area per capita and to Professor Lynn Jamieson (University of Edinburgh), Dr Trivess Moore (Royal Melbourne Institute of Technology University) and Dr Katherine Keenan (University of St Andrews) for their helpful comments. This research was made possible by a Carnegie Trust Research Incentive Grant (Grant number: RIG007515).

\section{Financial and non-financial competing interest Statement:}

The author declares no competing interests.

\begin{abstract}
Techno-economic approaches largely avoid delineating necessary energy uses or questioning how excessive lifestyle expectations may curtail attempts to achieve ambitious climate change targets. In this Perspective I present data suggesting a general trend of increasing domestic floor area per capita globally and argue that this ought to be a key focus in future energy research considering that house size is the largest determinant of domestic energy consumption. Particular attention should be directed at the confluence of factors that influence floor area per capita and questions of lifestyle expectations, energy sufficiency, and invisible energy policies which have enabled the rise in floor area per capita both deliberately and inadvertently. Overall, this elucidates why energy research must consider lifestyle expectations and demographic trends that are generally seen as outside the remit of energy policy.
\end{abstract}

\section{Introduction}

Despite extensive investment in efficiency, global energy consumption continues to rise. As such, it is now widely agreed that any effective response to avoid risky climate change will require new ways of living, working and relaxing. ${ }^{1}$ This is in part because there are limits to the dominant strategies of energy efficiency improvements and behaviour change campaigns, as these approaches take existing understandings of energy needs for granted and do not radically challenge social conditions in which needs are defined. ${ }^{2}$ Furthermore, global demographic changes and processes of (sub)urbanisation undermine energy reduction from technical solutions. In this Perspective I bring together government data sets on floor area per capita which, combined with previously published data on house and household size, suggest that increasing house size and parallel demographic trends of decreasing household size are resulting in a global shift towards more domestic space per person, which may significantly impact energy consumption. This highlights opportunities for energy researchers to contribute to debates over the human drivers of carbon emissions ${ }^{3}$ and homes in on an apparent contradiction: why do we need larger homes for smaller households? Declining household size 
has substantial demographic momentum, but rising house size is the result of norms and policies that can be changed ${ }^{4}$. Thus, the final section of this Perspective points to areas of invisible energy policy_non-energy policies which have unacknowledged, or insufficiently acknowledged, impacts on energy demand ${ }^{2}$ - deserving more attention in energy research.

\section{Household size, house size, and floor area per capita}

Household size decline has important energy implications ${ }^{5,6}$ and shifts in household size are an important determinant of energy consumption and carbon emissions per capita ${ }^{4,7,8,9,10}$. This research, largely emerged from household and environmental demography, highlights the neglect of households in development studies and suggests that household size is often a better predictor of carbon emissions than population ${ }^{3,7,8,9}$. The decline in household size is a global trend. For instance, Bradbury et al. ${ }^{7}$ found that household size has been declining increasingly since 1900 and most low- and middle-income countries have also seen an accelerated decline since 1987, albeit with erratic patterns. Currently around $40 \%$ of Scandinavian households and $30 \%$ of UK and US households are one-person households ${ }^{11}$.

Even though social and economic development often slows rates of population growth (e.g. declining total fertility rate), development also yields more and smaller households ${ }^{7}$. This can increase consumption per capita in terms of building more houses and the carbon emissions embedded in construction and materials in the home (e.g. cement, timber, glass, plastic, electrical goods) and due to a loss of economies of scale and sharing ${ }^{4,7,8,9,10}$. For instance, there is a greater demand for household goods such as refrigerators, internet routers and washing machines as these are not shared within a larger household. The energy for baseload demands such as heating are also greater per capita as they are not shared amongst as many household members. Across a range of national contexts, other things being equal, smaller households have been found to increase (direct and indirect) energy and resource consumption, waste generation, and biodiversity loses ${ }^{8,12}$.

Yet there is little empirical testing of the mechanisms for why co-habiting would reduce consumption per capita and norms of sharing and how communality is practiced is oversimplified $^{13}$. For example, individuals living alone can be creative in strategies to achieve economies of scale (i.e. cook in bulk and freeze leftovers) and can still be part of wider communities that might share food, tools, or clothing. Nonetheless, an empirical study suggests that on average an additional household member reduces carbon emissions by $6 \%$ per capita ${ }^{12}$. This study cautioned that decline in household sizes is outstripping another potential benefit of development to reduced carbon emissions: increased urban density. Indeed, declining household size is often attributed to suburban sprawl and anti-suburban narratives, especially in relation to environmental sustainability (see Charmes $\& \mathrm{Kiel}^{14}$ for critical assessment of the preference for density in urban studies).

Housing and urban policy studies have commonly discussed the need and demand for alternative housing forms due to wide recognition of decreasing household $\operatorname{size}^{15}$. Urban studies importantly explore the environmental impact of demographic changes and suburban spraw $1^{16,17}$ often focusing on the energy implications of construction, travel patterns and infrastructures, environmental impact from consumption broadly, or modelling on a metropolitan or neighbourhood scale (cf. Charmes \& Keil ${ }^{14}$; Gray et al. ${ }^{17}$; Stephan et al. ${ }^{18}$ ). However, there are still underexplored gaps relevant to addressing the paradox of decreasing household size and increasing house size, such as why small households do not live in small houses ${ }^{15,19}$ or how floor area per capita, as opposed to density of housing, influences energy consumption per capita. 
Within energy research, house size has received limited attention despite clear evidence that building characteristics such as house size and typology are the largest determinant and predictors of energy consumption (see Huebner \& Shipworth ${ }^{20}$ for an excellent overview), accounting for up to $42 \%$ of performance variability ${ }^{20,21,22}$. In comparison, the impact of occupant characteristics such as household size and income is much lower, ranging from 4.2 to $20 \%{ }^{21}$. Moreover, increasing house sizes in high-income countries are negating energy savings from improved efficiency standards and building regulations ${ }^{5,6,23,24}$. For instance, Clune et al. ${ }^{23}$ calculated that increased house sizes in Australia decreased efficiency standards by $38 \%$ over a 6 -year period. Other research has found that a smaller house built to a lower energy standard in many cases uses less energy than a large house built to a high standard ${ }^{6,23,24}$. Indeed, large houses are often not built in more efficient ways as features such as grand staircases (e.g. double height spaces) or multiple roof lines (e.g. complex geometry) to present a grand entrance are more likely, despite their impact on building performance ${ }^{6,24}$. This should be a significant concern in domestic energy research and policy considering evidence of increasing house sizes in high-income countries ${ }^{5,6}$. For instance, Viggers and colleagues ${ }^{6}$ find that while flats and apartments in Australia, Canada, New Zealand, The UK and the US have stayed a similar size over the past century there has been a significant increase in larger detached homes. Previous domestic energy research has generally considered only household or house size, without bringing them together to explore their joint influence on domestic floor area per capita.

Based on government data from thirteen countries, Fig. 1 gives an indication of a general increasing trend in floor area per capita, with the highest average of $84 \mathrm{~m}^{2}$ in Australia (2009) and the lowest stable average in India of $7.7 \mathrm{~m}^{2}(1960)$ to $8.7 \mathrm{~m}^{2}$ (2008). Upper-middle (China, Russia) and lower-middle income countries (Cambodia, India, Vietnam) generally have lower average floor area per capita than high income countries (Australia, Denmark, Germany, Hong Kong, Japan, Taiwan, United Kingdom, United States of America), but these averages do not capture variations due to urban and rural divides (i.e. Hong Kong data highlights space per capita constrained by urban density) or low and high income within a country. There are limitations to these comparisons as government's measure house size differently (e.g. measurement by the external wall or internal usable space, inclusion or not of garages or second houses), definitions of "household" have varied across time and between countries, and there are variations in how measures of occupation and house size are combined. Nevertheless, these data suggest that changes in house size and household size are converging to result in increasing floor area per capita. This has implications for energy consumption per capita considering that space heating and cooling are the main use for energy in homes (i.e. buildings account for nearly a third of global final energy consumption: three-quarters of this is domestic buildings and nearly $70 \%$ is for heating ${ }^{25}$ ). Thus, despite efficiency improving globally and reducing the energy use per unit of floor area at an average annual rate of $1.3 \%$, the growth of floor area, which has an average annual growth rate of $3 \%$ globally, results in rising demand ${ }^{26}$. 


\section{Fig 1. Change in domestic floor area per capita over time}

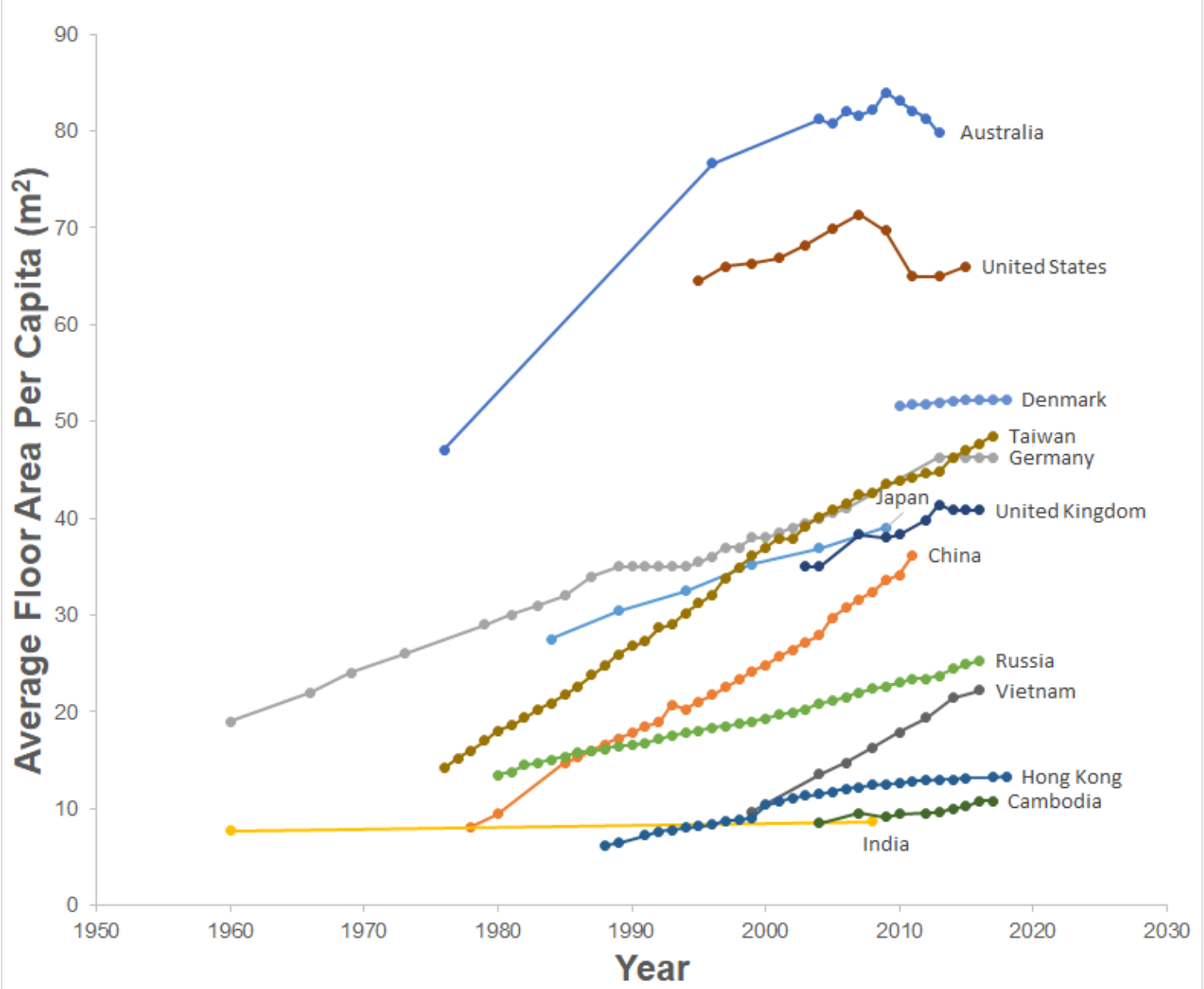

\section{Influence of demographic changes}

Declining household size is one aspect of advanced societies undergoing urbanisation and postindustrialisation and has been a pattern recognised since the 1980s as the 'second demographic transition' (see Lesthaeghe ${ }^{27}$ for an excellent overview and Sobotka ${ }^{28}$ who highlight diversity and complexity in how this manifests in different countries). Fertility declines, partnering and parenting are delayed, divorces and household dissolutions increase, and the number of multigenerational households decrease ${ }^{7,10}$. In some countries, increased flexibility in transitions to adulthood result in more opportunities throughout the life course to live alone while remaining parents are living longer and maintaining smaller households after children move out ${ }^{7,29}$. These shifts are generally attributed to an increase in income (e.g. less dependent on economies of scale to meet the cost of domestic goods); a shift in ideals and the importance of selfactualisation, autonomy and individual privacy (e.g. urbanisation and living in cities results in more human contact, with the home becoming a greater source of escape and autonomy); and a reduced availability of kin to co-habit with (e.g. sharing a home is seen as a family matter and this intimacy is not extended to strangers and friends) $)^{3,9,30}$. The implication is not just that household size decline can, or should, be stopped due to its impact on energy consumption per capita $^{3,8,12}$, but rather that these trends raise opportunities to consider engaging with invisible energy policies and relate to understanding changing expectations of energy needs.

First, in demographic literature the desire for increased privacy is commonly identified (although debated) as a driver of declining household sizes ${ }^{7,30}$ because the second demographic 
transition is founded on the rise of 'higher order needs' such as self-actualisation and individual autonomy ${ }^{27}$. Arguably, experiencing greater autonomy could shift images of a desirable home life and make people more resistant to sharing their (future) homes. For example, although preferences vary between cultures ${ }^{31}$, after living on your own during higher education, you may be less willing to move back with your parents or in with your partner's kin and the inclination instead is to set up your own household ${ }^{29}$.

Second, declining fertility, mortality and morbidity present novel challenges which also have implications for energy consumption per capita ${ }^{9}$. Older people are increasingly living alone, with figures as high as halve of over 65 years olds in high income countries ${ }^{32}$. For example, in Japan there has been a shift from taking care of parents being 'a natural duty' of children with $66 \%$ of women surveyed in 1950 expecting children to support them in old age decreasing to $16 \%$ expecting this forty years later due to not wanting to be a burden ${ }^{32}$. With the decline of multi-generational households, 'empty-nesters' may be advised to invest in energy efficiency or undertake energy saving activities but one of the most effective ways for them to reduce their consumption is by downsizing or taking on lodgers: recommendations generally seen as outside of the remit of energy advice and policy ${ }^{20,33}$.

Downsizing has benefits for energy reduction, yet the mismatch between the number of bedrooms households have versus need is generally uncontested ${ }^{20}$. There are numerous reasons why people would be unwilling or unable to downsize: strong attachment to one's home; a perceived lack of storage in smaller dwellings; fear of losing autonomy if moving to collective housing; not wanting to leave the wider community and networks of support in which their home is situated; protecting inheritance and financial security; and a lack of adequate housing options to move to ${ }^{20,34}$. Importantly, these final two issues highlight clear avenues for energy research and policy. First, capital gains, real estate transfer or stamp duty land taxes result in a financial loss for householders and concessions on these have been identified by multiple authors as a key way to support downsizing ${ }^{5,20,24}$. Second, developers have been widely criticised for failing to build a range of options to allow for downsizing in many high-income countries $^{20,23}$. For example, in German cities, $40-50 \%$ of the population live in one person households and 30\% in two person households yet 3-4 room flats are most common. The result is two to three times as many one person households as 1-2 room flats ${ }^{5}$. Longer life spans and a desire for more privacy suggests changing needs over the life course and there are opportunities to provide more flexible housing forms. For example, homes that have bedroom(s) that can be adapted for renting to avoid extra space before or after having children, communal housing that has shared facilities to accommodate guests, and co-housing. Energy researchers should engage with architects, urban planners and developers on attractive alternative designs that respond to the needs of smaller household sizes and predicted future demographics.

\section{Discussion}

The trends identified above of increasing house sizes and floor area per capita undoubtedly impact expectations of home comfort and aspirations for the ideal home. Just as standardisation and globalisation has resulted in homogenisation of indoor temperatures across the globe over the past forty years ${ }^{35}$, so too can increasing floor area per capita shift norms and expectations of how much space is 'enough'. Consequently, the notion of energy sufficiency is important; absolute reduction in domestic energy demand cannot be achieved without measures to limit average floor area per capita ${ }^{5}$. 
Challenging the perception that 'bigger is better' is a clear area for future energy research considering the emphasis on house size as a determinant of energy demand and that living in appropriately sized homes significantly impacts energy consumption ${ }^{19,22}$. Instead of information and behaviour change campaigns on savings from upgrading boilers or installing efficient light bulbs, marketing could target the drawbacks of larger homes (i.e. affordability, cost of heating/cooling, more time and labour to clean and maintain, unsuitability later in life with stairs); instead of eco-home road shows, showing off high-quality, compact homes could shift perceptions of space needs ${ }^{24,36,37}$. Furthermore, regulations that could encourage developers to shift their own practices are needed. For instance, measuring an house's total energy demand rather than the current dominant practice of calculating energy efficiency by $\mathrm{m}^{2}$ which incentivises building larger homes because larger homes benefit from economies of scale ${ }^{5,6,23,24}$. Moreover, covenants by developers which establish minimum floor areas or restrict sub-divisions limit options for creating small, space-efficient homes ${ }^{23,24}$; the rationale for covenants and their variability presents an avenue for future research. Finally, changes to government land-use zoning could encourage denser residential areas and more building around transport hubs $2,{ }^{23,24}$. Indeed, policies supporting urban infill (e.g. granny flats and tiny houses) could encourage more diverse and affordable housing ${ }^{23}$. Considering the demographic trends identified above more small and even short term accommodation are needed to meet changing housing needs over the life course (e.g. young adults moving out earlier and living on own, older generations wanting to maintain autonomy and privacy).

Moreover, energy researchers should not simply focus on restricting increasing house sizes but should also ensure that housing provides adequate occupant satisfaction in terms of privacy and personal space as this is assumed to be a part of modernisation and a driver towards smaller household sizes. Drawing on the rich literature on meaning and making of home $e^{38,39}$ and the $\mathrm{OECD}^{40}$ framing of the basic necessities of housing suggests that having a sense of control and 'being able to do what you want' is arguably as important to occupant's wellbeing as ensuring housing allows occupants to be sufficiently warm or cool. For example, in the UK, poor soundproofing and disturbance from neighbours is one of the most common complaints about living in flats and justification for the desire for a detached house ${ }^{41}$. Improving standards of visual and acoustic privacy in high-density housing or creating opportunities for personalisation in rented accommodation (e.g. not being able to decorate in rented properties, halls of residence) present other invisible energy policies that could improve satisfaction with smaller, communal and high-density forms of housing necessary to reduce absolute energy consumption.

In conclusion, floor area per capita ought to be a key focus in future energy research considering that house size is the largest determinant of domestic energy consumption ${ }^{20,21,22}$ and is on the rise $e^{5,6}$ at the same time as household sizes are declining globally $y^{4,8,10,12}$ and smaller households have been found to increase (in)direct energy consumption ${ }^{8,12}$. Smaller households, potentially driven by increased expectations of privacy, self-actualisation and individual autonomy, are recognised to be part of the process of development and (sub)urbanisation ${ }^{7,10,15,27}$. Increasing floor area per capita and numbers of bedrooms and bathrooms in homes highlight these changing collective conventions that shift perceptions of what is necessary for a basic standard of living. Techno-economic approaches largely avoid delineating necessary energy uses or questioning how excessive lifestyle expectations may curtail attempts to achieve ambitious climate change targets. There is thus much to be gained from engaging with invisible energy policies such as the ways in which housing standards, zoning regulations, and marketing of home improvement impacts house size and floor area per capita. Exploring the notion of energy sufficiency, challenging the perception that 'bigger is better,' measuring energy efficiency by building rather than $\mathrm{m}^{2}$, engaging with land-use zoning regulations, and improving standards of visual and acoustic privacy present ways forward to 
connect processes that have significant, yet largely ignored or invisible, impacts on energy demand.

\section{Fig. 1 Caption}

Citations identify sources for each data point and clarification is provided on variation in measures for some countries: Australia: $1976 \& 1996^{41} ; 2004-2013^{42}$. Australian data is only on average floor area for new residential buildings (rather than a sample of the whole housing stock) and these figures were divided by the average household size for the closest corresponding year. Cambodia: 2004-201744,45,46,47,48,49,50,51,52,53. China: 1978-2012 ${ }^{54}$. The Chinese dataset distinguished between rural and urban floor area per capita. Rural figures (2$5 \mathrm{~m}^{2}$ higher than the urban measure) were used because these provide a continuous dataset from 1978 while the urban measure is distinguished from 2002. Denmark: 2010-2018 ${ }^{55}$. Germany: 1960-2006 ${ }^{56}$. Hong Kong: 1988-2018 $57,58,59,60,61,62,63,64,65,66,67,68$. Figures for Hong Kong are based on public housing only. India: $1957^{69} ; 2008^{70}$. Japan: 1993-2013 ${ }^{71}$. Japanese data collected every 5 years, including average floor area per dwelling and average household size in the same census. Russia: 1980-2016 $6^{72}$. Taiwan: 1976-2017 $7^{73}$. United Kingdom: 2003$2007^{74,75,76} ; 2009-2016^{77,78,79,80,81,82,83,84}$. UK figures are based on English data, which does not calculate floor area per capita and mean floor area was divided by the average household size for the closest corresponding year. US: 1993-2015 $-2016^{96,97,98,99,100,101}$.

\section{Reference List}

1. Shove, E. Beyond the ABC: climate change policy and theories of social change. Environ. Plann A 42, 1273-1285 (2010).

2. Royston, S., Selby, J. \& Shove, E. Invisible energy policies: A new agenda for energy demand reduction. Energ. Policy 123, 127-135 (2018).

3. Rosa, E.A. \& Dietz, T. Human drivers of national greenhouse-gas emissions. Nat. Clim. Change 2, 581 (2012).

4. Peterson, M.N., Peterson, T. \& Liu, J. The housing bomb: why our addiction to houses is destroying the environment and threatening our society (JHU Press, 2013).

5. Lorek, S. \& Spangenberg, J.H. Energy sufficiency through social innovation in housing. Energ. Policy 126, 287-294 (2019).

6. Viggers, H., Keall, M., Wickens, K. \& Howden-Chapman, P. Increased house size can cancel out the effect of improved insulation on overall heating energy requirements. Energ. Policy 107, 248-257 (2017).

7. Bradbury, M., Peterson, M. N. \& Liu, J. (2014). Long-term dynamics of household size and their environmental implications. Popul.Environ. 36, 73-84 (2014).

8. Liu, J., Daily, G.C., Ehrlich, P.R. \& Luck, G.W. Effects of household dynamics on resource consumption and biodiversity. Nature 421, 530-533 (2003).

9. O'Neill, B.C. \& Chen, B.S. Demographic determinants of household energy use in the United States. Popul. Dev. Rev. 28, 53-88 (2002).

10. Underwood, A. \& Zahran, S. The carbon implications of declining household scale economies. Ecol. Econ. 116, 182-190 (2015).

11. UNECE. Proportion of one-person households in all households. (United Nations Economic Commission for Europe, 2015). Available at: https://w3.unece.org/PXWeb/en/Charts? IndicatorCode=318\&CountryCode=826 
12. Fremstad, A., Underwood, A. \& Zahran, S. The environmental impact of sharing: household and urban economies in CO2 emissions. Ecol. Econ. 145, 137-147 (2018).

13. Yates, L. Sharing, households and sustainable consumption. J. Consum. Cult. 18, 433452 (2018).

14. Charmes, E. \& Keil, R. The politics of post-suburban densification in Canada and France. Int. J. Urban Reg. Res. 39, 581-602 (2015).

15. Wulff, M., Reynolds, M. \& Healy, E. Why don't small households live in small dwellings?: disentangling a planning dilemma. People and Place 12, 58 (2004).

16. Dunham-Jones, E. \& Williamson, J. Retrofitting suburbia: urban design solutions for redesigning suburbs (John Wiley \& Sons, 2008).

17. Gray, R., Gleeson, B. \& Burke, M. Urban consolidation, household greenhouse emissions and the role of planning. Urban Pol. Res. 28, 335-346 (2010).

18. Stephan, A., Crawford, R. H., \& De Myttenaere, K. Multi-scale life cycle energy analysis of a low-density suburban neighbourhood in Melbourne, Australia. Building and Environ. 68, 35-49 (2013).

19. Dowling, R. \& Power, E. Sizing home, doing family in Sydney, Australia. Housing Stud. 27, 605-619 (2012).

20. Huebner, G. M., \& Shipworth, D. All about size?-The potential of downsizing in reducing energy demand. Appl. Energy 186, 226-233 (2017).

21. Santin, O. G., Itard, L. \& Visscher, H. The effect of occupancy and building characteristics on energy use for space and water heating in Dutch residential stock. Energ. Buildings 41, 1223-1232 (2009).

22. Huebner, G. M., Hamilton, I., Chalabi, Z., Shipworth, D. \& Oreszczyn, T. Explaining domestic energy consumption-the comparative contribution of building factors, socio-demographics, behaviours and attitudes. Appl. Energy 159, 589-600 (2015).

23. Clune, S., Morrissey, J. \& Moore, T. Size matters: House size and thermal efficiency as policy strategies to reduce net emissions of new developments. Energ. Policy 48, 657-667 (2012).

24. Wilson, A. \& Boehland, J. Small is beautiful US house size, resource use, and the environment. J. Ind. Ecol. 9, 277-287 (2005).

25. REN21. Renewables 2018 Global Status Report (Renewable Energy Policy Network for the 2st Century, 2018). Available at: http://www.ren21.net/wpcontent/uploads/2018/06/17-8652_GSR2018_FullReport_web_final_.pdf

26. IEA. Tracking Clean Energy Progress 2017 (International Energy Agency, 2017). Available at:

https://www.iea.org/publications/freepublications/publication/TrackingCleanEnergyPr ogress2017.pdf

27. Lesthaeghe, R. The second demographic transition: A concise overview of its development. Proc. Nat. Acad. Sci. 111, 18112-18115 (2014).

28. Sobotka, T. Overview chapter 6: The diverse faces of the second demographic transition in Europe. Dem. Res. 19, 171-224 (2008).

29. Jamieson, L. \& Simpson, R. Living alone: Globalization, Identity and Belonging (Springer, 2013).

30. Burch, T.K. \& Matthews, B.J. Household formation in developed societies. Popul. Dev. Rev. 13, 495-511 (1987). 
31. Albertini, M. \& Kohli, M. The generational contract in the family: An analysis of transfer regimes in Europe. Eur. Sociol. Rev. 29, 828-840 (2012).

32. UN. Living Arrangements of Older Persons Around the World. Department of Economic and Social Affairs, Population Division (United Nations, 2005).

33. Palm, J. The public-private divide in household behavior: How far into home can energy guidance reach?. Energ. Policy 38, 2858-2864 (2010).

34. Sixsmith, J. et al. (2014). Healthy ageing and home: The perspectives of very old people in five European countries. Social Science \& Medicine 106, 1-9 (2014).

35. Shove, E. Comfort, Cleanliness and Convenience (Berg, 2003).

36. Penfold, H., Waitt, G. \& McGuirk, P. Portrayals of the tiny house in electronic media: challenging or reproducing the Australian dream home. Aust. Plan. 1-10 (2019).

37. Susanka, S. \& Obolensky, K. The not so big house: A blueprint for the way we really live (Taunton Press, 2001).

38. Ellsworth-Krebs, K., Reid, L., \& Hunter, C. J. Home-ing in on domestic energy research: "House," "home," and the importance of ontology. Energy Res. Soc. Sci. 6, 100-108 (2015).

39. Ellsworth-Krebs, K., Reid, L., \& Hunter, C. J. (2019). Integrated framework of home comfort: relaxation, companionship and control. Build. Res. Inf. 47, 202-218 (2019).

40. OECD. Better Life Index: Housing (The Organisation for Economic Co-operation and Development, 2019) Available at: http:/www.oecdbetterlifeindex.org/topics/housing/

41. CABE. What home buyers want: Attitudes and decision making among consumers (Commission for Architecture \& the Built Environment, 2005)

42. ABS. Construction and the environment, Yearbook of Australia (Australian Bureau of Statistics, 2013). Available at:

http://www.abs.gov.au/AUSSTATS/abs@.nsf/Previousproducts/1301.0Feature\%20Ar ticle282003.

43. ABS. Building Activity Survey, Total New Residential/Census average number of person per household (Australian Bureau of Statistics, 2013). Available at:

http://www.abs.gov.au/AUSSTATS/abs@.nsf/Previousproducts/8752.0Feature\%20Ar ticle1Jun\%202013

44. NIS. Cambodia Socioeconomic Survey 2004 (National Institute of Statistics, Ministry of Planning, Royal Kingdom of Cambodia, 2004). Available at:

http://www.nis.gov.kh/index.php/en/national-statistical-systems/official-statistics-ofcambodia/14-cses/39-cses-2004-report

45. NIS. Cambodia Socioeconomic Survey 2007 (National Institute of Statistics, Ministry of Planning, Royal Kingdom of Cambodia, 2007). Available at: http://www.nis.gov.kh/nis/CSES/NIS_CSES_Report_Housing_final200809.pdf

46. NIS. Cambodia Socioeconomic Survey 2009 (National Institute of Statistics, Ministry of Planning, Royal Kingdom of Cambodia, 2009). Available at: http://www.nis.gov.kh/nis/CSES/Final\%20Report\%20CSES\%202009.pdf

47. NIS. Cambodia Socioeconomic Survey 2010 (National Institute of Statistics, Ministry of Planning, Royal Kingdom of Cambodia, 2010). Available at: http://www.nis.gov.kh/nis/CSES/Final\%20Report\%20CSES\%202010.pdf

48. NIS. Cambodia Socioeconomic Survey 2012. (National Institute of Statistics, Ministry of Planning, Royal Kingdom of Cambodia, 2012). Available at: http://www.nis.gov.kh/nis/CSES/Final\%20Report\%20CSES\%202012.pdf 
49. NIS. Cambodia Socioeconomic Survey 2013. (National Institute of Statistics, Ministry of Planning, Royal Kingdom of Cambodia, 2013). Available at: http://www.nis.gov.kh/nis/CSES/Final\%20Report\%20CSES\%202013.pdf

50. NIS (2014). Cambodia Socioeconomic Survey 2014. (National Institute of Statistics, Ministry of Planning, Royal Kingdom of Cambodia, 2014). Available at: http://www.nis.gov.kh/nis/CSES/Final\%20Report\%20CSES\%202014.pdf

51. NIS. Cambodia Socioeconomic Survey 2015. (National Institute of Statistics, Ministry of Planning, Royal Kingdom of Cambodia, 2015). Available at: http://www.nis.gov.kh/nis/CSES/Final\%20Report\%20CSES\%202015.pdf

52. NIS. Cambodia Socioeconomic Survey 2016. (National Institute of Statistics, Ministry of Planning, Royal Kingdom of Cambodia, 2016). Available at: http:/www.nis.gov.kh/nis/CSES/Final\%20Report\%20CSES\%202016.pdf

53. NIS. Cambodia Socioeconomic Survey 2017. (National Institute of Statistics, Ministry of Planning, Royal Kingdom of Cambodia, 2017). Available at: http://www.nis.gov.kh/nis/CSES/Final\%20Report\%20CSES\%202017.pdf

54. NBS. Floor Space of Newly Built Residential Buildings. (National Bureau of Statistics of China, 2014). Available at: http://www.stats.gov.cn/tjsj/ndsj/2014/zk/html/Z0617E.htm

55. SD. Dwellings with registered population (average) by Area, Unit, and Use. (StatBank Denmark, 2018). Available at: https://www.statbank.dk/statbank5a/selectvarval/define.asp?PLanguage=1\&subword= tabsel\&MainTable $=$ BOL106\&PXSId $=206367 \&$ tablestyle $=\& S T=$ SD\&buttons $=0$

56. Noll, H-H., \& Weick, S. Housing in Germany: Expensive, Comfortable and Usually Rented. (Informationsdienst Soziale Indikatoren - ISI selected English articles, 2014). Available at: https://www.gesis.org/fileadmin/upload/forschung/publikationen/zeitschriften/isi/isi41 -NollWeick-English.pdf

57. HA. Housing in Figures 1995. (Hong Kong Housing Authority, 1995). Available at: http://www.cityu.edu.hk/hkhousing/hs/figures/HIF_1995_part_1.pdf

58. HA. Housing in Figures 1996. (Hong Kong Housing Authority, 1996). Available at: http://www.cityu.edu.hk/hkhousing/hs/figures/HIF_1996_part_2.pdf

59. HA. Housing in Figures 1997. (Hong Kong Housing Authority, 1997). Available at: http://www.cityu.edu.hk/hkhousing/hs/figures/HIF_1997_part_2.pdf

60. HA. Housing in Figures 1998. (Hong Kong Housing Authority, 1998). Available at: http://www.cityu.edu.hk/hkhousing/hs/figures/HIF_1998_part_1.pdf

61. HA. Housing in Figures 1999. (Hong Kong Housing Authority, 1999). Available at: http://www.cityu.edu.hk/hkhousing/hs/figures/HIF_1999_part_1.pdf

62. HA. Housing in Figures 2010. (Hong Kong Housing Authority, 2010). Available at: http://www.cityu.edu.hk/hkhousing/hs/figures/Housing_in_Figures_2010_c.pdf

63. HA. Housing in Figures 2011. (Hong Kong Housing Authority, 2011). Available at: http://www.cityu.edu.hk/hkhousing/hs/figures/Housing_in_Figures_2011_c.pdf

64. HA. Housing in Figures 2012. (Hong Kong Housing Authority, 2012). Available at: http://www.cityu.edu.hk/hkhousing/hs/figures/Housing_in_Figures_2012_c.pdf

65. HA. Housing in Figures 2013. (Hong Kong Housing Authority, 2013). Available at: http://www.cityu.edu.hk/hkhousing/hs/figures/Housing_in_Figures_2013_c.pdf 
66. HA. Housing in Figures 2014. (Hong Kong Housing Authority, 2014). Available at: http://www.cityu.edu.hk/hkhousing/hs/figures/Housing_in_Figures_2014_c.pdf

67. HA. Housing in Figures 2015. (Hong Kong Housing Authority, 2015). Available at: http://www.cityu.edu.hk/hkhousing/hs/figures/Housing_in_Figures_2015_c.pdf

68. HA. Housing in Figures 2018. (Hong Kong Housing Authority, 2018). Available at: https://www.thb.gov.hk/tc/psp/publications/housing/HIF2018.pdf

69. ISI. The National Sample Survey, August 1956-January 1957. (Indian Statistical Institute, the Cabinet Secretariat: Government of India, 1961). Available at: http://www.mospi.nic.in/sites/default/files/publication_reports/nss_rep_51.pdf

70. NBO. State of Housing in India, A Statistical Compendium. (National Buildings Organisation, Government of India, 2013). Available at: http://nbo.nic.in/Images/PDF/Housing_in_India_Compendium_English_Version.pdf

71. SB. Households, Household Members and Size of Dwelling by Prefecture, Housing 21-1, Japan Statistical Yearbook 2016. (Statistics Bureau, Ministry of Internal Affairs and Communications, 2016). Available at: http://www.stat.go.jp/english/data/nenkan/65nenkan/1431-21.html

72. Rosttat. Construction activity and housing provision in Russia (translated from Russian). (Rosttat, Federal States Statistic Service, 2017). Available at: http://rusfact.ru/node/28

73. DGBAS. Housing Living Situation by Year (translated from Mandarin Chinese). (National Statistics, Directorate General of Budget, Accounting and Statistics, Executive Yuan, R.O.C. (Taiwan), 2016). Available at: http://statdb.dgbas.gov.tw/pxweb/dialog/..\%5CDialog\%5Cviewplus.asp?ma=FF0008 $\mathrm{A} 1 \mathrm{~A} \& \mathrm{ti}=\% \mathrm{AEa} \% \mathrm{AEx} \% \mathrm{~A} 6 \% \mathrm{ED} \% \mathrm{~A} 6 \mathrm{v} \% \mathrm{AA} \% \mathrm{AC} \% \mathrm{AAp} \% 20 \% 20-$ $\% \mathrm{~A} 6 \sim$ \&path=../PXfile/HouseholdFinances/\&lang=9\&strList $=\mathrm{L}$

74. EHCS. English House Condition Survey 2003 Annual Report. (Office of the Deputy Prime Minister, 2003). Available at: http://doc.ukdataservice.ac.uk/doc/6103/mrdoc/pdf/6103annual_report.pdf

75. EHCS. English House Condition Survey 2004 Annual Report. (Office of the Deputy Prime Minister, 2004). Available at: http://doc.ukdataservice.ac.uk/doc/6104/mrdoc/pdf/6104annual_report.pdf

76. EHCS. English House Condition Survey 1996 Summary. (Department for Communities and Local Government, 2006). Available at: http://doc.ukdataservice.ac.uk/doc/6101/mrdoc/pdf/6101ehcs_1996_summary.pdf

77. EHCS. English House Condition Survey 2007 Annual Report. (Department for Communities and Local Government, 2007). Available at: http://doc.ukdataservice.ac.uk/doc/6449/mrdoc/pdf/6449ehcs_annual_report_2007.pdf

78. EHS. English Housing Survey, Headline report 2009-10. (Department of Communities and Local Government, 2011). Available at: http://doc.ukdataservice.ac.uk/doc/6804/mrdoc/pdf/6804ehs_headline_report_2009_1 $0 . p d f$

79. EHS. English Housing Survey, Headline report 2010-11. (Department of Communities and Local Government, 2012). Available at: http://doc.ukdataservice.ac.uk/doc/7039/mrdoc/pdf/7039_ehs_headline_report_201011.pdf 
80. EHS. English Housing Survey, Headline report 2012-13. (Department of Communities and Local Government, 2014). Available at:

http://doc.ukdataservice.ac.uk/doc/7511/mrdoc/pdf/7511_ehs_headline_report_201213.pdf

81. EHS. English Housing Survey, Headline report 2013-14. (Department of Communities and Local Government, 2015). Available at:

http://doc.ukdataservice.ac.uk/doc/7802/mrdoc/pdf/7802_english_housing_survey_he adline_report_2013-14.pdf

82. EHS. English Housing Survey, Headline report 2014-15. (Department of Communities and Local Government, 2016). Available at:

http://doc.ukdataservice.ac.uk/doc/8009/mrdoc/pdf/8009_ehs_headline_report_201415.pdf

83. EHS. English Housing Survey, Headline report 2015-16. (Department of

Communities and Local Government, 2017). Available at:

http://doc.ukdataservice.ac.uk/doc/8185/mrdoc/pdf/8185_2015-

16_ehs_headline_report.pdf

84. EHS. English Housing Survey, Headline report 2015-16. (Department of

Communities and Local Government, 2018). Available at:

http://doc.ukdataservice.ac.uk/doc/8350/mrdoc/pdf/8350_2016-

17_ehs_headline_report.pdf

85. AHS. American Housing Survey for the United States in 1993. (American Housing Survey, US Census Bureau, 1995). Available at:

https://www.census.gov/content/dam/Census/library/publications/1995/demo/h150_9 3.pdf

86. AHS. American Housing Survey for the United States in 1995. (American Housing Survey, US Census Bureau, 1997). Available at: https://www.census.gov/content/dam/Census/library/publications/1997/demo/h150_9 5rv.pdf

87. AHS. American Housing Survey for the United States in 1997. (American Housing Survey, US Census Bureau, 2000). Available at: https://www.census.gov/prod/99pubs/h150-97.pdf

88. AHS. American Housing Survey for the United States in 2001. (American Housing Survey, US Census Bureau, 2002). Available at: https://www.census.gov/prod/2002pubs/h150-01.pdf

89. AHS. American Housing Survey for the United States in 1999. (American Housing Survey, US Census Bureau, 2003). Available at: https://www.census.gov/content/dam/Census/programs-surveys/ahs/data/1999/h15099.pdf

90. AHS. American Housing Survey for the United States in 2003. (American Housing Survey, US Census Bureau, 2004). Available at: https://www.census.gov/prod/2004pubs/H150-03.pdf

91. AHS. American Housing Survey for the United States in 2005. (American Housing Survey, US Census Bureau, 2006). Available at: https://www.census.gov/prod/2006pubs/h150-05.pdf 
92. AHS. American Housing Survey for the United States in 2007. (American Housing Survey, US Census Bureau, 2008). Available at: https://www.census.gov/prod/2008pubs/h150-07.pdf

93. AHS. American Housing Survey for the United States in 2009. (American Housing Survey, US Census Bureau, 2011). Available at: https://www.census.gov/prod/2011pubs/h150-09.pdf

94. AHS. American Housing Survey for the United States, Table Generator. (US Census Bureau, 2019). Available at: https://www.census.gov/prod/2011pubs/h150-09.pdf

95. UN Habitat. Vietnam Housing Sector Profile. (United National Habitat for a Better Urban Future, 2013). Available at: https:/unhabitat.org/vietnam-housing-sectorprofile/.

96. GSO. Result of the Viet Nam Household Living Standards Survey 2006. (General Statistics Office of Viet Nam, 2006). Available at: https://www.gso.gov.vn/default_en.aspx?tabid=515\&idmid=5\&ItemID=8183

97. GSO. Result of the Survey on Household Living Standards 2008. (General Statistics Office of Viet Nam, 2008). Available at: https://www.gso.gov.vn/default_en.aspx?tabid=515\&idmid=5\&ItemID=9647

98. GSO. Result of the Viet Nam Household Living Standards Survey 2010. (General Statistics Office of Viet Nam, 2010). Available at: https://www.gso.gov.vn/default_en.aspx?tabid=515\&idmid=5\&ItemID=12426

99. GSO. Result of the Viet Nam Household Living Standards Survey 2012. (General Statistics Office of Viet Nam, 2012). Available at: https://www.gso.gov.vn/default_en.aspx?tabid=483\&idmid=4\&ItemID=13888

100. GSO. Result of the Viet Nam Household Living Standards Survey 2014. (General Statistics Office of Viet Nam, 2014). Available at: http://www.gso.gov.vn/default.aspx?tabid=512\&idmid=\&ItemID=18410

101. GSO. Result of the Viet Nam Household Living Standards Survey 2016. (General Statistics Office of Viet Nam, 2016). Available at: https://www.gso.gov.vn/default_en.aspx?tabid=515\&idmid=5\&ItemID=18977 